\title{
FOUR NEW SPECIES AND ONE NEW SUBSPECIES OF ASTEROIDEA (ECHINODERMATA) COLLECTED BY THE "SIBOGA" EXPEDITION IN THE INDO-MALAYAN REGION
}

\author{
by \\ AZNAM AZIZ* \& MICHEL JANGOUX \\ Laboratoire de Biologie marine (C.P. 160), Université Libre de Bruxelles, 50 avenue F. D. Roosevelt, \\ B-1050 Bruxelles, Belgium
}

\section{ABSTRACT}

Four new species and one new subspecies of asteroids collected by the "Siboga" Expedition in the Indo-Malayan region are described. They are deep-water species belonging to the families Goniasteridae, Solasteridae, Ganeriidae, Asteriidae and Brisingidae.

\section{RÉSUMÉ}

Quatre espèces et une sous-espèce nouvelles d'Astérides récoltés dans la région indo-malaise par l'Expédition "Siboga" sont décrites. Ce sont des formes d'eaux profondes appartenant aux familles des Goniasteridae, Solasteridae, Ganeriidae, Asteriidae et Brisingidae.

\section{INTRODUCTION}

The asteroid material collected by the "Siboga" Expedition (1899-1900) in the IndoMalayan region has for the greater part been investigated by Döderlein (1917-1936). Examination of the unidentified specimens allowed us to recognize up to four species and one subspecies of Asteroidea that are new to science. These species belong to the following genera: Evoplosoma (Goniasteridae), Solaster (Solasteridae), Hyalinothrix (Ganeriidae), Anteliaster (Asteriidae) and Brisingenes (Brisingidae). We thank Prof. Dr. S. Van der Spoel, Curator of Marine Invertebrates of the Institute of Taxonomic Zoology (Zoölogisch Museum), University of Amsterdam, who gave us the opportunity to study that collection.

* Present address: National Institute of Oceanology, P.O. Box 580, Jakarta 11001, Indonesia.

\section{LIST OF STATIONS}

Sta. 012: 14 Mar. $1899,07^{\circ} 15^{\prime} \mathrm{S} \quad 115^{\circ} 15^{\prime} .6 \mathrm{E}$, depth 289 $\mathrm{m}$, mud and broken shells.

Sta. 045: 6 Apr. $1899,07^{\circ} 24^{\prime} S \quad 11^{\circ} 15^{\prime} .2 \mathrm{E}$, depth 794 $\mathrm{m}$, fine grey mud with some radiolarians and diatoms.

Sta. 085: 17 June $1899,00^{\circ} 36^{\prime} .5 \mathrm{~S} 119^{\circ} 29^{\prime} .5 \mathrm{E}$, depth $724 \mathrm{~m}$, fine grey mud.

Sta. 245: 3 Dec. $1899,04^{\circ} 16^{\prime} .5 \mathrm{~S} 130^{\circ} 15^{\prime} .8 \mathrm{E}$, depth $4956 \mathrm{~m}$, traces of bluish green mud.

Sta. 246: 4 Dec. $1899,04^{\circ} 38^{\prime} \mathrm{S} 130^{\circ} 42^{\prime} \mathrm{E}$, depth 5684 $\mathrm{m}$, solid fine greyish green mud with a rather brown upper layer.

Sta. 286: 19 Jan. $1900,08^{\circ} 50^{\prime} .2 \mathrm{~S} \quad 127^{\circ} 2^{\prime} .2 \mathrm{E}$, depth 883 $\mathrm{m}$, thin layer of mud.

Sta. 314: $17 \mathrm{Feb} .1900,07^{\circ} 36^{\prime} .6 \mathrm{~S} 117^{\circ} 30^{\prime} .8 \mathrm{E}$, depth $694 \mathrm{~m}$, fine sandy mud.

\section{DESCRIPTION OF THE SPECIES}

Evoplosoma timorensis sp. nov.

(Plate I)

Material. - One specimen (holotype), dry, "Siboga" Exped. sta. 286 (Zoölogisch Museum Amsterdam coll. no. ZMA E. 1207).

Diagnosis. - A species of Evoplosoma with round primary abactinal plates bearing a central blunt-tipped spine. Secondary abactinal plates spineless. Both primary and secondary abactinals surrounded by a peripheral series of coarse granules. Superomarginals with 1-2 blunt-tipped central spines. Inferomarginal with 3-6 short spines. Actinolateral plates usually with 1 elongated central spine. Marginal and actinolateral plates surrounded by a peripheral series of coarse granules. Proximal adambulacral plates with 6-7 strongly compressed furrow spines and 1 stout subam- 
bulacral spine. Oral plates with 13-15 compressed marginal spines and 3-5 prismatic suboral spines. Occurrence of large excavate pedicellariae with elongated spatulate jaws on most actinal plates.

Description. $-\mathrm{R}=90 \mathrm{~mm}, \mathrm{r}=23 \mathrm{~mm}$, $\mathrm{R}=4 \mathrm{r}$, five arms. Disk large, subpentagonal and relatively convex aborally. Arms elongated, tapering and more or less circular in cross section. Primary abactinal plates rounded and slightly convex, up to $2.5 \mathrm{~mm}$ in diameter. Most of them bear a central, stout, blunt-tipped spine (mean length: $3 \mathrm{~mm}$ ). Primary plates surrounded by a peripheral series of $15-25$ coarse, rounded granules, the surface between the central spine and the peripheral granules being deprived of armament. Secondary abactinal plates flat, polygonal to rounded, without armament except a peripheral series of 5-10 coarse, rounded granules. Most of the primary plates of the disk and of the proximal part of the arms not contiguous and separated from each other by secondary plates. Primary plates forming three regular longitudinal series on the proximal part of the arms.

Marginal plates squarish and rather conspicuous. Superomarginals slightly tumid, confined to the side of disk and arms; 23-25 superomarginals in each series. Each plate with 2-3 (disk) to 1 (arms) central spines similar in shape but smaller than the primary abactinal spines. Inferomarginals of arms slightly shorter than superomarginals; $27-28$ inferomarginals in each series. Each plate with 6-8 (disk) to 2-3 (arms) short blunt-tipped spines, more or less transversally arranged. Both supero- and inferomarginal plates surrounded by a peripheral series of 40-60 coarse granules.

Actinal intermediate plates flat, polygonal in shape, the more radial plates being the largest. Most of them with 1 (rarely 2 or 3 ) elongated blunt-tipped central spines (maximal length: 2 $\mathrm{mm}$ ), and surrounded by a peripheral series of coarse granules. Some plates have scattered additional granules located between the central spine and the peripheral series.

Proximal adambulacral plates with 6-7 broad, elongated, strongly compressed furrow spines and 1 stout almost cylindrical elongated subambulacral spine (maximal length: 2.5 $\mathrm{mm}$ ). Adambulacral plates in the middle of the arms with 5-6 furrow spines and 2-3 rather small subambulacral spines. Each plate with a series of 5-6 coarse granules on its adradial edge. Oral plates with 13-15 elongated, strongly compressed marginal spines and 3-4 elongated, prismatic, suboral spines. A series of 10-11 coarse prismatic granules occur along the median suture of each paired oral plate.

Papulae single, confined to the abactinal surface. No papulae on the distal end of the arms nor on the lateral margin of the interradial disk areas. Madreporic plate circular, slightly larger than the centrodiscal primary abactinal plates. A large excavate pedicellaria with upright spatulate jaws on each adambulacral plate (subambulacral pedicellariae) and on most actinolateral plates. Similar pedicellariae may occur on some primary abactinal and some proximal inferomarginal plates.

Discussion. - Two species have been assigned to the genus Evoplosoma, viz. E. forcipifera Fisher, 1906, and $E$. augusti Koehler, 1909. In his original description Fisher (1906: 1065) emphasized the occurrence of a soft membrane which covers the whole body "hiding the calcareous part and causing the granulation to have a crowded, soft, warty appearance". According to Koehler (1909) that membrane is much thinner in $E$. augusti. It has not been observed in $E$. timorensis. Moreover, Fisher reported that the membrane shrinks greatly when the individuals are dry. Therefore it is possible that the absence of such a membrane in $E$. timorensis is related to the dry condition of the specimen. Otherwise $E$. timorensis fits well within the generic diagnosis of Evoplosoma (see Fisher, 1906: 1065), e.g. with respect to the characters of both the abactinal and adambulacral skeleton as well as to the shape of the pedicellariae. The most marked differences between $E$. timorensis and the two previously described species concern the general form of the individuals and the armature of the abac- 

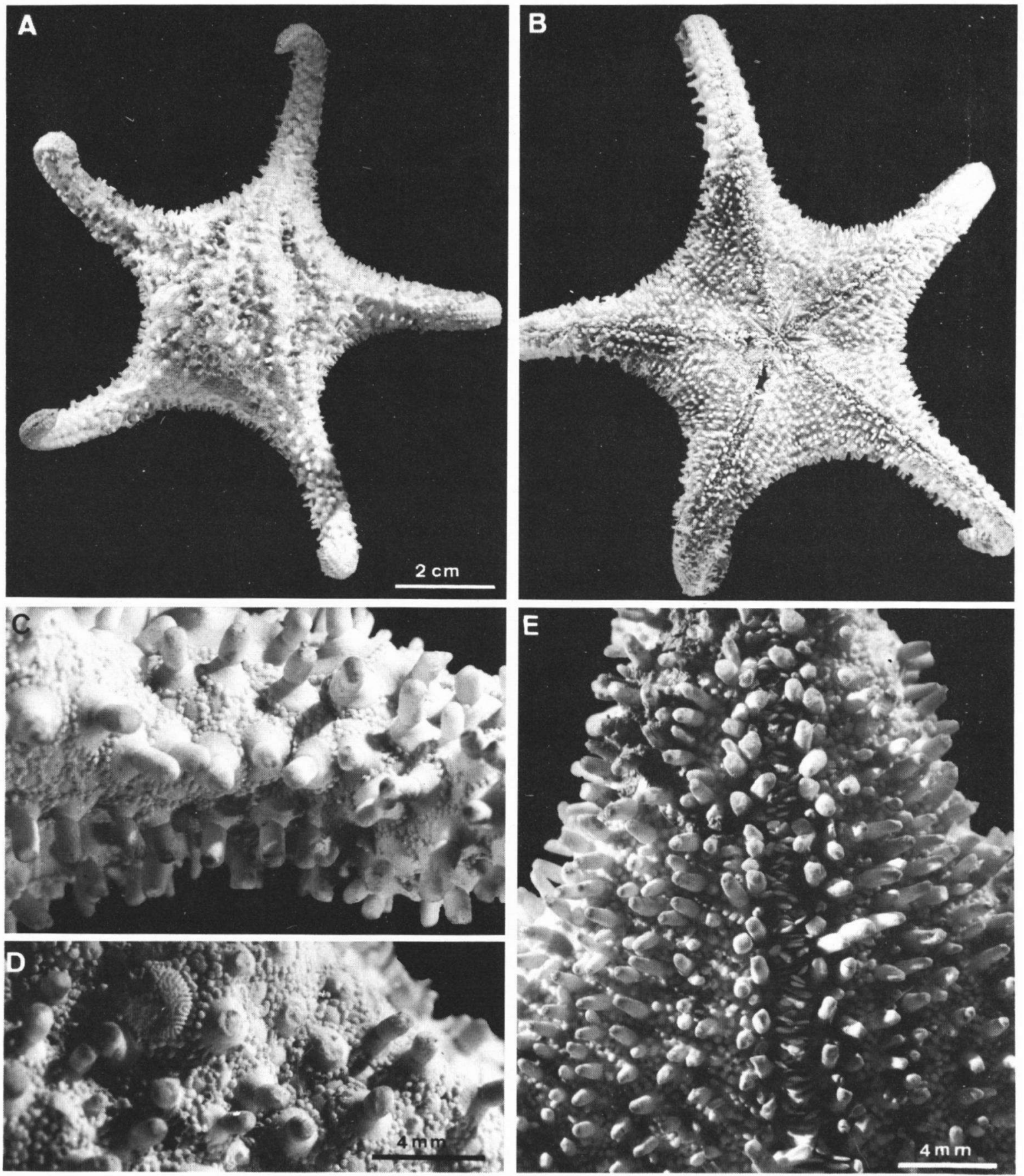

Plate I

Evoplosoma timorensis sp. nov.: A, B, aboral und oral views; C, abactinal skeleton of the arm base; D, abactinal skeleton of the madreporic interradius; $\mathrm{E}$, actinal skeleton of the arm base. 
tinal plates (no abactinal spines in $E$. augusti; the occurrence of a central conical spine and abactinal plates entirely covered with granules in E. forcipifera). Excepting the armature of the oral plates, there is a strong resemblance in the actinal characters of both $E$. forcipifera and $E$. timorensis.

\section{Solaster paxillatus celebesensis subsp. nov. (Plate II)}

Material. - One specimen (holotype), dry, "Siboga" Exped. sta. 85 (ZMA E. 1238); one specimen (paratype), preserved in alcohol, "Siboga" Exped. sta. 85 (ZMA E. 1253).

Diagnosis. - A subspecies of Solaster paxillatus with 8 arms. Differing from $S$. paxillatus paxillatus in the armature of the skeletal plates, viz. less numerous abactinal spines (10 to 15$)$ and more numerous inferomarginal and furrow spines (60 to 80 and 6 to 7 , respectively). Inner series of actinal intermediate plates rather short, not extending beyond the 10th inferomarginal plates.

Description of the holotype. $-\mathrm{R}=98$ $\mathrm{mm}, \mathrm{r}=26 \mathrm{~mm}, \mathrm{R}=3.8 \mathrm{r}, 8$ arms. Disk relatively large, slightly depressed aborally. Arms elongated, tapering to a blunt-pointed end. Abactinal plate rather delicate, three- to four-lobed, each plate with a small central pseudopaxilla, about 0.5 to $1.0 \mathrm{~mm}$ in diameter. Abactinal plates spaced by 2 to 4 times their width. Pseudopaxillae irregularly arranged, except on the sides of the proximal part of the rays where they form regular oblique-transverse series. Each pseudopaxilla with 10 to 15 short multifid spinelets. Abactinal armament more or less hidden by the skin.

Marginal plates in two distinct series. Superomarginals small, paxilliform, subequal with adjacent abactinal plates; each pseudopaxilla with 10 to 15 short, thorny spinules. Inferomarginals alternating with superomarginals. Inferomarginal plates conspicuous, 46 to 48 in each series, each with a transversely elongated paxilla bearing 60 to 80 short thorny spinelets and 1 to 3 short spines, up to $1 \mathrm{~mm}$ in length on its adradial edge.
Actinal intermediate areas narrow, the intermediate plates forming 3 longitudinal series on each side of the arms. Intermediate plate similar in shape to the abactinals, each pseudopaxilla with 4 to 8 short blunt-tipped spinules, more or less concealed by skin. Only the inner series of plates extends to the arm base (i.e. to the 4th inferomarginal plate), the others being limited to the disk.

Furrow spines 6 to 7 , united by web for half or two-thirds of their length. Furrow spines slightly flattened with a blunt tip, the median spines longer than the lateral ones. Subambulacral spines 4 to 5 , transversally arranged and united by web at their base. Subambulacral spines longer and stouter than the median furrow spines. Oral plates large with 13 to 15 marginal spines and 12 to 13 suboral spines, the latter arranged in two irregular longitudinal series.

Papulae prominent, 1 to 4 per abactinal mesh. Madreporic plate circular $(3.5 \mathrm{~mm}$ in diameter), partly obscured by abactinal paxillae.

Note on the paratype. $-\mathrm{R}=118 \mathrm{~mm}$, $\mathrm{r}=32 \mathrm{~mm}, \mathrm{R}=3.7 \mathrm{r}, 8$ arms. Abactinal pseudopaxillae with up to 20 spinules; 1 to 5 papulae per abactinal mesh. Inner series of actinal intermediate plates may reach up to the 10th inferomarginal plates. Furrow spines 6 to 7 , subambulacral spines 6 to 7 .

Discussion. - The "Siboga" specimens show intermediate characters between the species Solaster paxillatus Sladen, 1889 and Solaster tropicus Fisher, 1913, the latter being considered by Fisher (1919) as allied to $S$. paxillatus. They differ mostly from $S$. tropicus in having more numerous paxillar spinelets and more numerous furrow spines as well as much shorter series of actinal intermediate plates (the inner series extending nearly to the tip of the ray in S. tropicus). The "Siboga" specimens are more related to $S$. paxillatus (see diagnosis), the latter being known only from the north-east Pacific area (north of Japan, Behring Sea and south of Alaska; see Fisher, 1911a; Hayashi, 1973). 


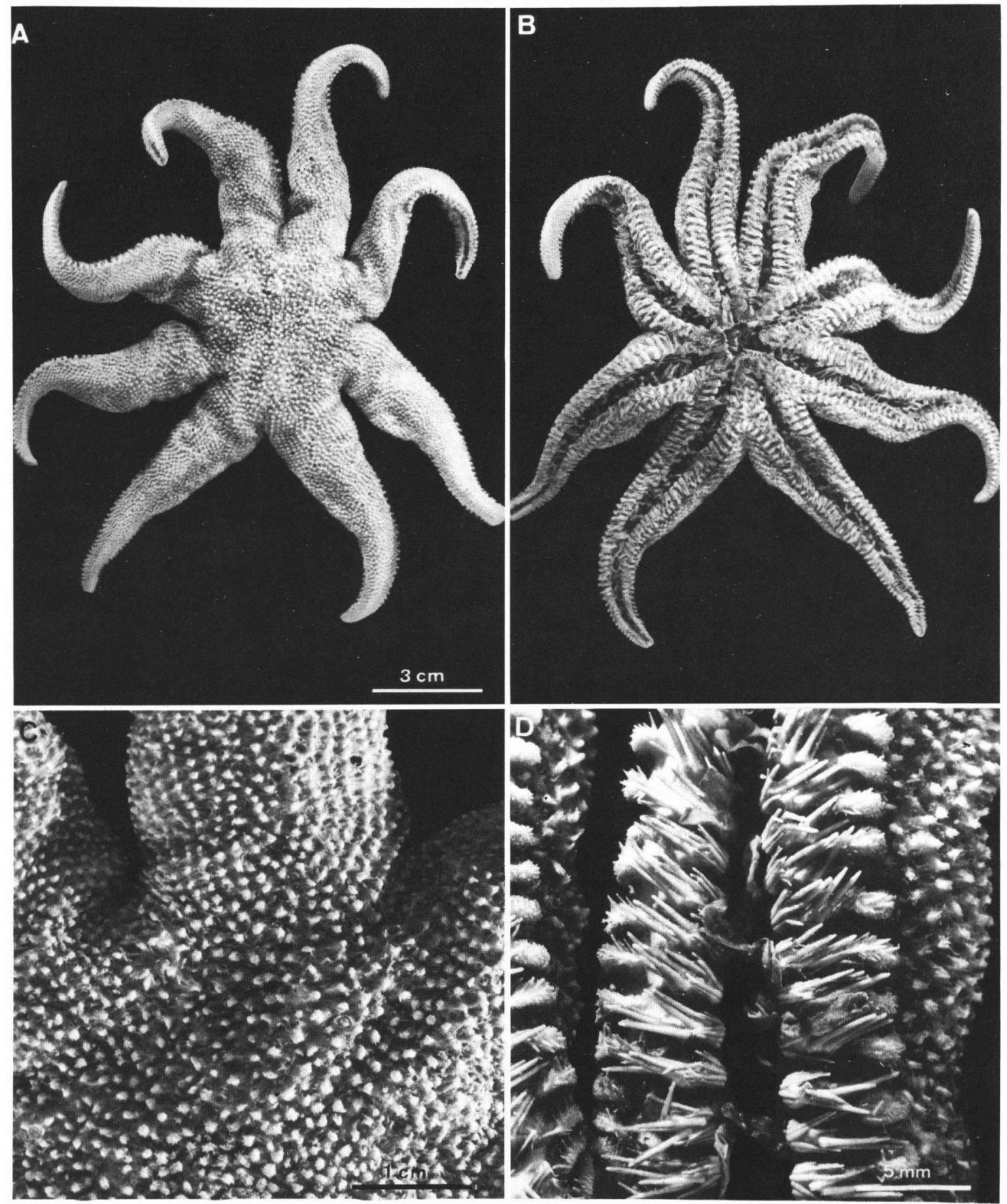

Plate II

Solaster paxillatus celebesensis subsp. nov. (holotype): A, B, aboral and oral views; C, abactinal armament of the disk and the arm base; $D$, armament of the adambulacral and inferomarginal plates. 
Hyalinothrix gracilis sp. nov. (Plate III)

Material. - One specimen (holotype), dry, "Siboga" Exped. sta. 246 (ZMA E. 1206).

Diagnosis. - A species of Hyalinothrix with three- or four-lobed abactinal plates. Abactinal plates with low tabula bearing up to 40 small glassy spinules. Papulae single. Marginal plates small, rectangular in shape. Actinal intermediate plates confined to the interradial areas of the disk. Marginal and actinolateral plates paxilliform, each with a low tabulum tipped by 25 to 40 spinules. Adambulacral plates with 4 to 5 furrow spines forming a longitudinal series, and a group of about 25 subambulacral spinules.

Description. - $R=37 \mathrm{~mm}, \mathrm{r}=7 \mathrm{~mm}$, $\mathrm{R}=5.4 \mathrm{r}$, width at arm base $7 \mathrm{~mm}, 5$ arms. Disk relatively small. Arms cylindrical, elongated and tapering to a sharply pointed distal end. Abactinal skeleton made of three- or four-lobed tabulate plates. The plates are not regularly arranged on the center of the disk and on the midradial area of the arms, while on the side of the arms they form regular straight as well as oblique transverse series. The tabulum of each plate is short and rather convex. The largest tabula at the arm base or on the disk bear up to 40 small needle-like glassy spinules with sharply pointed tip. The length of the spinules is almost equal to the height of their tabulum.

Marginal plates small and rectangular in shape, bearing pseudopaxillae similar to those of the abactinal plates. Marginal series strictly parallel to the adambulacral series except at the arm base; 64 to 65 superomarginals and 59 to 60 inferomarginals in each series, the inferomarginals being slightly larger than the superomarginals.

Actinal intermediate plates forming 3 to 4 longitudinal series on each side of the arms. The adradial series with 9-10 plates extends to the 10th or 11th inferomarginals which correspond to the arm base. Other series with 4 to 5 , 2 to 3 and 1 plates, respectively. Each plate has a low tabulum bearing about 25 to 30 spinules.
Adambulacral plates rectangular in shape, wider than long and slightly larger than the adjacent actinal plates. There are 4-5, mostly 5, elongated and slender furrow spines with a blunt thorny tip. These spines are webbed at their base. Furthermore, 20 to 25 subambulacral spinules borne by a convex subambulacral nodule, the most adradial spinules being enlarged but always smaller than the furrow spines. Oral plates with 7-8 marginal spines and a few suboral spinules.

Papulae single, distributed all over the abactinal surface except the arm tips and the more marginal interradial areas of the disk. Madreporic plate circular, partly hidden by the abactinal pseudopaxillae. No pedicellariae. Anal aperture subcentral and conspicuous.

Discussion. - H. gracilis fits perfectly within the generic diagnosis of Hyalinothrix proposed by Fisher (1911b). It differs from the single previously known species, Hyalinothrix millespina Fisher, in the shape of the arms (more tapering in $H$. gracilis) and in several skeletal characters such as the number of spinules on the abactinal pseudopaxillae (75-100 in $H$. millespina; up to 40 in $H$. gracilis), the development of the actinal intermediate series (confined to the interradius in $H$. gracilis; extending to the arm tip in $H$. millespina), and the number of furrow spines (4-5 in $H$. gracilis with $\mathrm{R}=37 \mathrm{~mm}, 3-4$ in $H$. millespina with $\mathrm{R}=45$ to $50 \mathrm{~mm}$ ).

As emphasized by Fisher (1911b) and Clark (1983), Hyalinothrix while being ascribed to the family Ganeriidae shows rather marked differences with the "classical" ganeriid genera such as Ganeria, Cycethra and Perknaster. On the contrary, clear affinities appear to occur between Hyalinothrix and the genus Seriaster recently described by Jangoux (1984). These affinities concern both the overall construction of the skeleton and the particular architecture of the pseudopaxillae.

\section{Anteliaster indonesiae sp. nov.}

(Plate IV)

Material. - One specimen (holotype), dry, "Siboga" Exped. sta. 12 (ZMA E. 1205). 

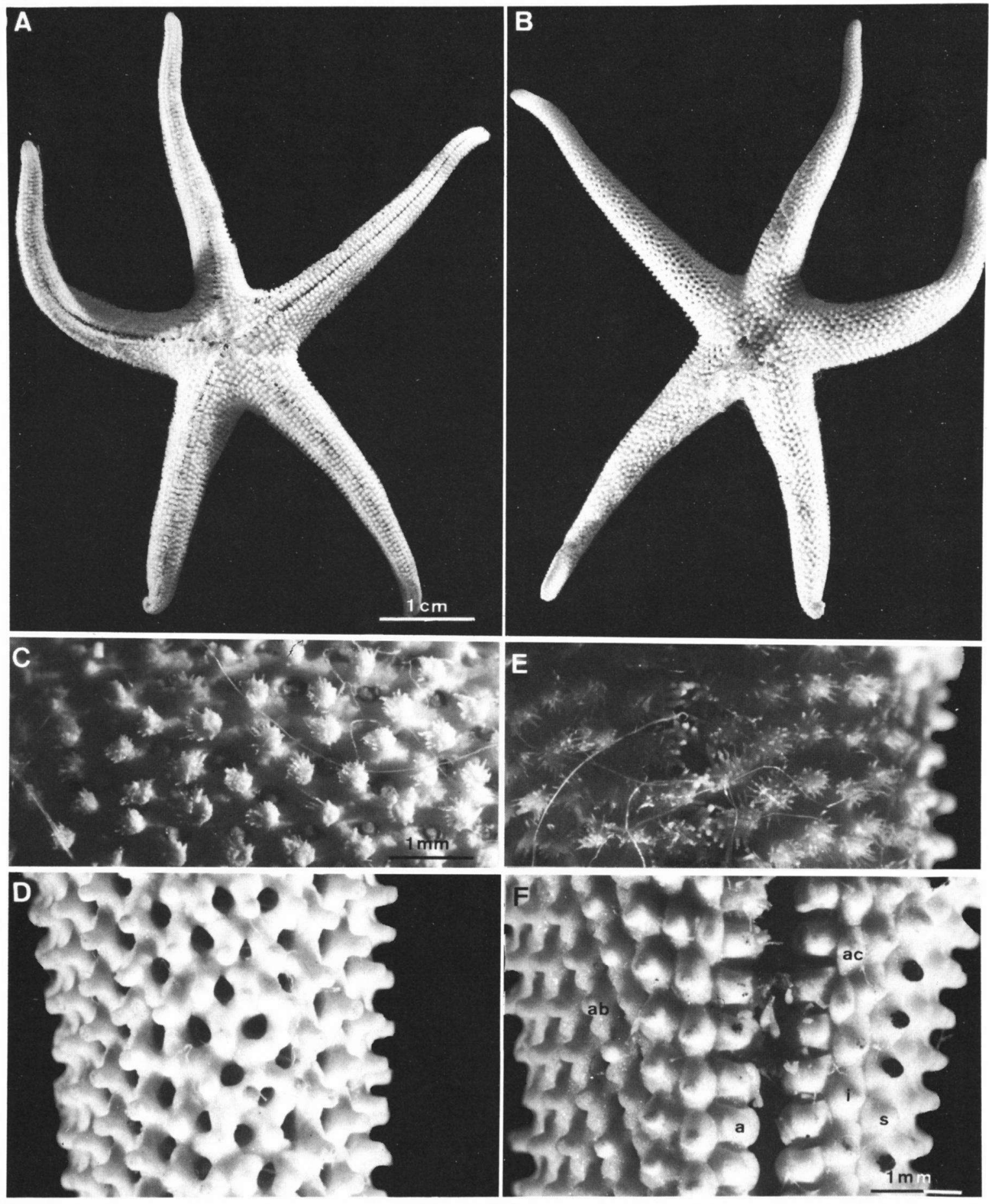

Plate III

Hyalinothrix gracilis sp. nov.: A, B, aboral and oral views; C, D, abactinal pseudopaxillae (C) and denuded abactinal skeleton (D); E, F, adambulacral plates with adjacent pseudopaxillae (E) and denuded actinal skeleton (F) (note the

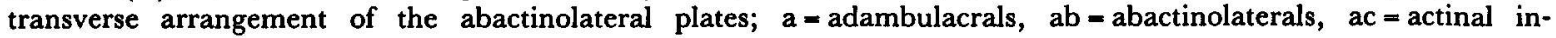
termediates, $\mathrm{i}=$ inferomarginals, $\mathrm{s}=$ superomarginals). 

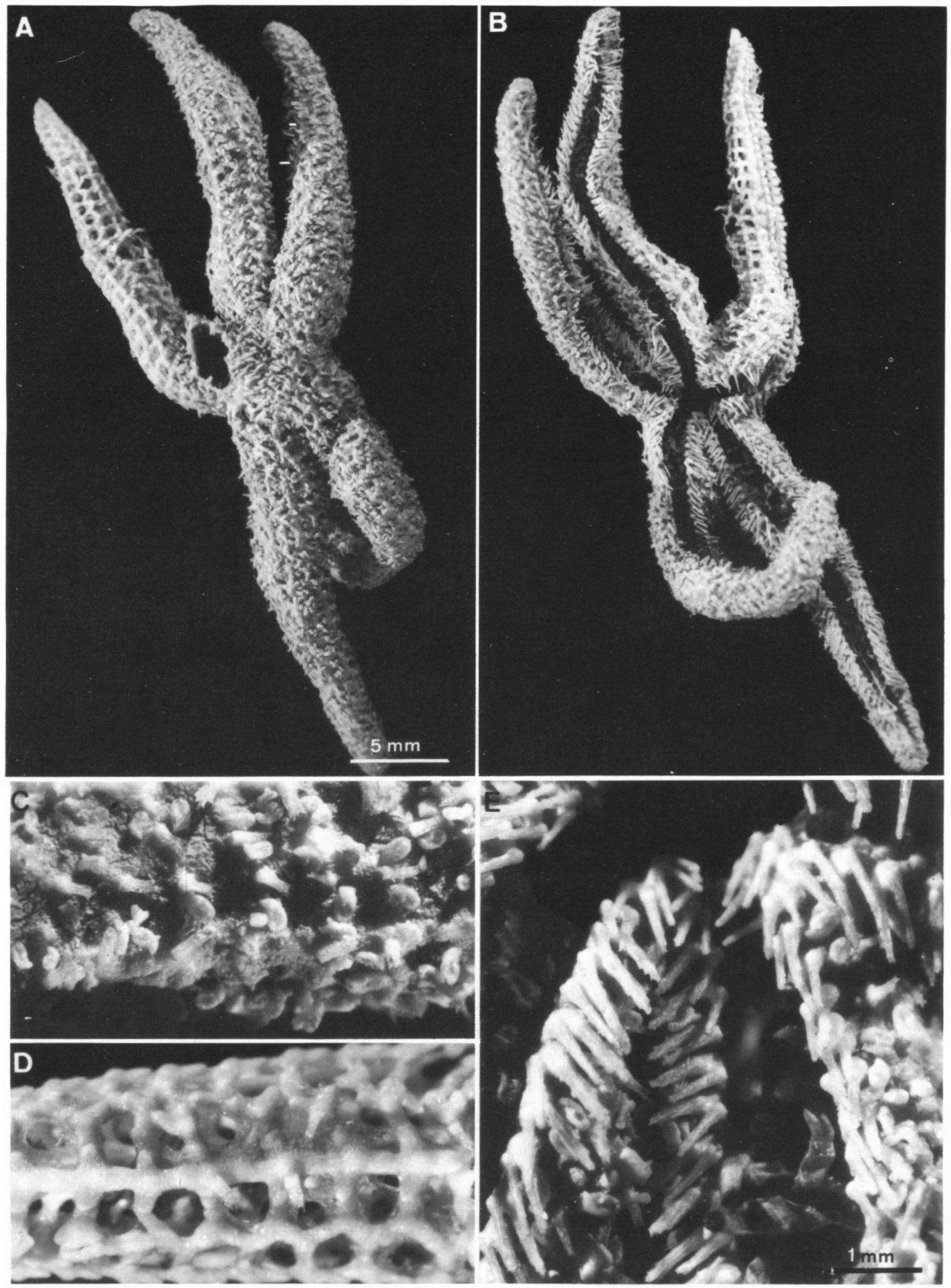

Plate IV

Anteliaster indonesiae sp. nov.: A, B, aboral and oral views; C, D, abactinal armament (C) and denuded abactinal skeleton (D) (note the occurrence of conspicuous enlarged crossed pedicellariae); E, armament of the adambulacral plates. 
Diagnosis. - A species of Anteliaster with four (carinal) or three (abactinolateral) lobed abactinal plates. Marginal plates cruciform. One series of actinolateral plates extending to half the arm length. Each abactinal, marginal and actinolateral plate with one, rarely two, small central multifid spines up to $0.5 \mathrm{~mm}$ in length. These plates bear one or more large crossed pedicellariae, subequal in length to the central spine. Adambulacral plates each with two spines arranged in a transverse-oblique series. Adambulacral spines up to $1.2 \mathrm{~mm}$ in length. Papulae single, occurring only in intermarginal and actinal meshes.

Description. - $R=22 \mathrm{~mm}, \mathrm{r}=4 \mathrm{~mm}$, $R=5.5 \mathrm{r}$, five arms. Disk small, arms elongated, subcylindrical, slightly tapering to a blunt end. Abactinal plates forming a regular series of carinal plates and one or two rather irregular abactinolateral series on each arm side. Carinal plates four-lobed and longitudinally imbricated. Abactinolateral plates three-lobed, longitudinally imbricated or linked by small interconnecting plates. Abactinal meshes large and irregular in form and arrangement, covered by a thin skin. Each plate with 1, rarely 2 , short central multifid spines up to $0.5 \mathrm{~mm}$ in length.

Superomarginal plates cruciform with four weakly developed lobes, the lobes of adjacent superomarginals in close contact with each other or slightly imbricated. Inferomarginals cruciform to oblong, parallel to the superomarginals. Intermarginal meshes smaller and more regular than the abactinal ones. Each marginal plate with a central spine similar to those of the abactinal plates.

One series of actinolateral plates on each side of the arms, extending to about half the arm length. Actinolateral plates triangular to oblong in shape, closely pressed against the adambulacral series (no meshes between the actinolaterals and the adambulacrals). Occurrence of small actinolateral meshes between the inferomarginal and actinolateral series. Each actinolateral plate with a central spine similar to those of the abactinal plates.
Adambulacral plates with two spines (up to $1.2 \mathrm{~mm}$ in length) arranged in an obliquetransverse series (adambulacrals diplacanthid all along the arm). Adambulacral spines slender, elongate and subprismatic, each with a thorny tip. Oral plates small, bearing 3 marginal and 2 suboral spines similar in both shape and size to the adambulacral spines.

Papulae single, occurring only in intermarginal and in some actinolateral meshes. Large single crossed pedicellariae up to $0.5 \mathrm{~mm}$ in height are seen on most abactinal, marginal and actinolateral plates. Their jaws have 5 to 6 small, pointed lateral teeth and a small denticulate distal end. Small straight pedicellariae occasionally occur on some abactinal plates (length of their jaws about $0.3 \mathrm{~mm}$ ). There are no large unguiculate straight pedicellariae. Tube feet biserial all along the adambulacral groove.

Discussion. - Up to now, the genus Anteliaster was known only from the North Pacific and the Southern Ocean (see Fisher, 1928; Clark, 1962). Anteliaster indonesiae is characterized by very large crossed pedicellariae, the height of which is similar to that of the abactinal and marginal spines. It shows some affinities with Anteliaster microgenys Fisher in having no abactinal papulae, a single series of actinolateral plates and small oral plates. It differs from $A$. microgenys mostly in the size of crossed pedicellariae and in the number of adambulacral spines ( 3 to 5 in $A$. microgenys, 2 in $A$. indonesiae).

\section{Brisingenes plurispinula sp. nov. (Plate V)}

Material. - One specimen (holotype), preserved in alcohol, "Siboga"' Exped. sta. 85 (ZMA E. 2600); two specimens, preserved in alcohol, "Siboga" Exped. sta. 45 (ZMA E. 2599); two specimens, preserved in alcohol, "Siboga" Exped. sta. 314 (ZMA E. 2601 2602).

Diagnosis. - A species of Brisingenes with abactinal plates of the disk bearing each a group of 2 to 5 small spinelets. There are 25-30 costae alternating with the adambulacral plates. Intercostal cutaneous spaces with 1 to 2 bands of 

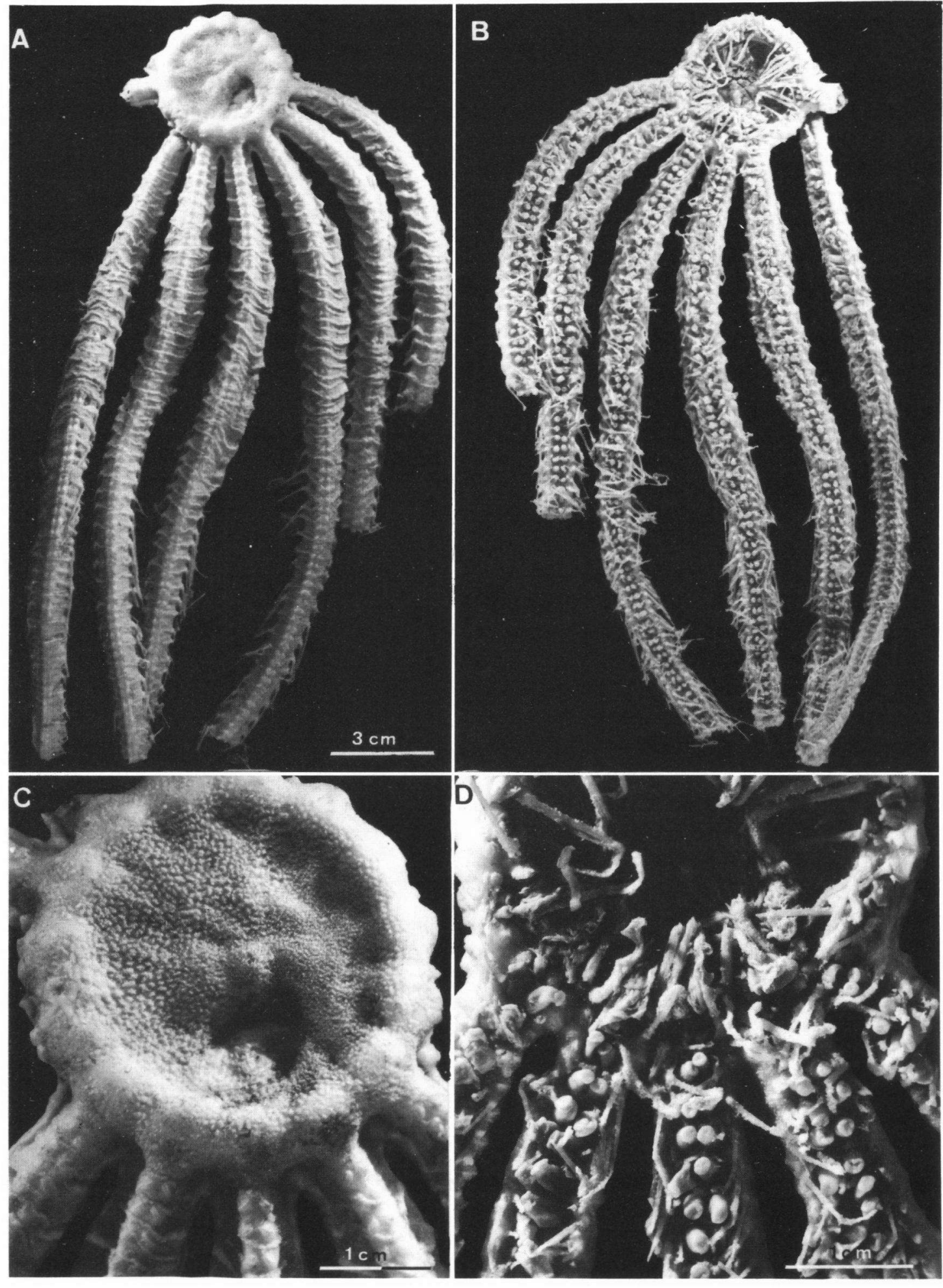

Plate V

Brisingenes plurispinula sp. nov. (holotype): A, B, aboral and oral views; C, D, enlarged views of the abactinal (C) and actinal (D) sides of the disk. 
pedicellariae. Adambulacral armature made of 1 large actinal spine, 1 adoral furrow spinule and 1 aboral furrow spinule.

Description. $-\mathrm{R}>295 \mathrm{~mm}, \mathrm{r}=19 \mathrm{~mm}, 15$ arms of which nine are broken between the 1 st and 2nd adambulacral plates. Disk relatively large, circular in shape with a slightly elevated margin. Small abactinal plates of the disk spaced by about their own diameter. Each plate bears a group of 2 to 5 small, subconical spinelets with thorny tip. The plates and spinelets are overlayered by a thin skin. Scattered small crossed pedicellariae from 0.15 to $0.20 \mathrm{~mm}$ height occur on the skin around the plates. Madreporic plate very small, measuring about $2 \mathrm{~mm}$ in diameter and located on the disk margin. Pairs of conspicuous papulae occur on the disk margin, directly over the first pair of adambulacral plates of each arm.

Arms very long, inflated and semicircular at genital areas, and more slender and subtriangular beyond the genital areas. About 25 to 30 prominent costae confined to genital areas. Each costal ridge consists of several small, more or less regularly arranged plates, each with 2 to 4 minute spinelets. The first costal plates above the adambulacral series is slightly enlarged and triangular in shape. Most of these adradial plates bear a long tapering prominent lateral spine, the length of which is equal to that of 3 succeeding adambulacral plates (within the genital areas) or of 4 to 5 succeeding adambulacral plates (beyond the genital areas). Costae and adambulacral plates are alternately arranged. Intercostal skin area thin and subtranslucent, without rudimentary plates and having usually 1 or 2 transverse bands of minute pedicellariae. Proximally the bands of pedicellariae may be replaced by small, incomplete costae. Crossed pedicellariae occur also on both the costae proper and their lateral spines.

Adambulacral plates longer than wide, and slightly constricted at mid-length. First adambulacral plates joined for their whole length to the corresponding plates of the adjacent ray. Adambulacral armature made of 1 small adoral furrow spinule, 1 large tapering actinal or subambulacral spine, and 1 small aboral furrow spinule. Adambulacral spines and spinules sheathed by skin and bearing numerous small crossed pedicellariae. The latter are larger than those of the disk and the costae, measuring from 0.40 to $0.45 \mathrm{~mm}$ in height. Oral plates with three marginal spines and one large, slender suboral spine. Suboral spines of contiguous oral plates are usually joined in a common sheath which prolongs beyond their tip. Many small crossed pedicellariae are seen on the outer surface of the sheath.

Note on other specimens. - The disk diameter varies from 32 to $41 \mathrm{~mm}$. The two specimens from station 314 have 16 arms. The lateral spines of the costae beyond the genital areas may be larger than in the holotype, as long as 6 succeeding adambulacral plates. One specimen from station 45 has 2 aboral furrow spinules on some adambulacral plates.

Discussion. - The genus Brisingenes was erected by Fisher (1917) for the species $B$. mimica. The two species of Brisingenes described previously - viz. B. mimica (Fisher, 1916) and B. anchista Fisher, 1919 - originate from the Philippine area (Fisher, 1919). Brisingenes plurispinula is related to $B$. mimica on account of the number of costae and the shape of the pedicellariae. It differs from it mainly in having grouped abactinal spinelets on the disk (single spinelets in $B$. mimica), costae alternating with the adambulacral plates, and intercostal bands of pedicellariae within the region of prominent costae.

\section{ACKNOWLEDGEMENTS}

We thank J. Harray for his technical assistance. This study was supported by an AGCD grant (Belgium) to A. Aziz.

\section{REFERENCES}

Clark, A. M., 1962. Asteroidea. Rep. B.A.N.Z. antarctic Res. Exped., (B) 9: 1-104, pls. 1-6.

- 1983 . Notes on Atlantic and other Asteroidea. 3. The families Ganeriidae and Asterinidae, with de- 
scription of a new asterinid genus. Bull. Br. Mus. nat. Hist. (Zool.), 45 (7): 359-380.

Döderlein, L., 1917-1936. Die Asteriden der SibogaExpedition. Siboga Exped., Monogr. XLVI (a-c, 1-3), Livr. 81 (1917): [i-vi], 1-191, pls. I-XVII; 88 (1920): [i-vi], 193-293, pls. XVIII-XX; 91 (1921): [i-iv], 1-47, pls. I-XIII; 98 (1924): [i-iv], 49-69, pls. XIV-XIX; 125 (1935): [i-iv], 71-110, pls. XXXXVII; 126 (1936): [i-vi], 295-369, pls. XXI-XXXII.

Fisher, W. K., 1906. The starfishes of the Hawaiian Islands. Bull. U.S. Fish Commn., 23 (3) "1903": 907-1130, pls. I-XLIX.

- 1911 a. Asteroidea of the North Pacific and adjacent waters. 1. Phanerozonia and Spinulosa. Bull. U.S. natn. Mus., 76 (1): i-iv, 1-419, pls. 1-122.

- $1911 \mathrm{~b}$. Hyalinothrix, a new genus of starfishes from the Hawaiian Islands. Proc. U.S. natn. Mus., 39: 659-664, pls. 69-71.
,-- 1917 . New genera and species of Brisingidae. Ann. Mag. nat. Hist., (8) 20: 418-427.

-, 1919 . Starfishes of the Philippine seas and adjacent waters. Bull. U.S. natn. Mus., 100 (3): i-xi, 1-712, pls. 1-156.

- - 1928. Asteroidea of the North Pacific and adjacent waters. II. Forcipulata (part). Bull. U.S. natn. Mus., 76 (2): i-iii, 1-245, pls. 1-81.

Hayashi, R., 1973. The sea-stars of Sagami Bay: 1-114, pls. 1-18 (Biological Laboratory, Imperial Household, Japan).

Jangoux, M., 1984. Les Astérides littoraux de NouvelleCalédonie. Bull. Mus. natn. Hist. nat. Paris, (4) 6 (A, 2): 279-293.

Koenler, R., 1909. Astéries recueillies par l'Investigator dans l'Océan Indien. I. Les Astéries de mer profonde. Echinoderma of the Indian Museum, 5: 1-143, pls. 1-13 (Trustees of the Indian Museum, Calcutta). 